\title{
オットー式スラツグベッドガス発生炬
}

一一昭和 32 年 6 月 18 日例会講演——

\section{東京瓦斯株式会社 高岛良一}

要旨：石炭の消費は世界各国共年々增加の一途をたぞり，特にコークス用原料炭は次第に制 約を受活てきている。石油資源の豊富なアメりカイイタリーなどを除いては石炭の有效利用， すなわわ原料炭以外の非粘結炭, 低品位炭のガス化を急速に工業化しなければならなぬ状沅に 追いつめられてきている。独乙に打いても非粘結炎の完全ガス化の研究が進み，大䙺模に工盖 化されて既に稼動中のルルギ高生ガス化装置, コッパーストッエックガス化装置に続いて, 1956 年にオットー式スラッグベッドガス発生炬がDüsseldorf の南方30哩の Cologne 市の Wesseling 合成工場に建設されて順調な作業を続けている。筆者はこの装置を見学する機会を得九 のでその装置の概要と作業成績の一例について述べた。

\section{I. 緒 言}

独乙のオットー社では Rummel 氏汇よつて提唱さ れたこのスラッグバッドガス発生炉を工業化するため に1950年に Düsseldorf 南約30哩の Cologne南のWesseling 合成工場に好理能力 $30 t /$ 日小規模な試験装 置を建設し，爾来5 ケ年間の実験を重ねて優秀な成績 収わたので，本格的な規模の装置を建設し1956年 5 月10日に運恸を開始した。筆者は同年 5 月24日作業開 始直後のこの装置を見学したが残念なことに一部修理 のため 5 月16日以来作業を休止していた。製造開始後 僅ふ5 日間の運転であるため新装置の作業成績ははつ きりしたものではなかつたが，Rummel 氏は大体了 期の成績を収めたと述へていた。Wesseling合成工場 は戦前は褐炭の液化を主として行つていたが，戦後禁 止されて現在はアンモニヤの合成, メタールの合成, 原油の水添などを行つているが，合成用原料がス孝従 来は主力をウインクラーがス発生师に依存していた。 今後は主力を次第にこのスラッグぶッドガス発生炉に 置換する方針で引続きさらに1基増設する計画で静い 售備を進めていた。

\section{I. 裝置の能力}

この本装置の設語の際の能力は次のと和りで山る。

$\begin{array}{ll}\text { ガス震造量 } & 16,000 \sim 18,000 \mathrm{~m}^{3} / \mathrm{hr} \\ \text { ぶス熱量 } & 2,600 \sim 2,800 \mathrm{kcal} / \mathrm{m}^{3} \\ \text { 原料使用量 } & 8 \sim 9 \mathrm{t} / \mathrm{hr}\end{array}$

(水分 $8 \%$ の褐孷として)

$\begin{array}{ll}\text { スラッグベッドの温度 } & 1,600 \sim 1,800^{\circ} \mathrm{C} \\ \text { 蒸気発生量 } & 9 \mathrm{t} / \mathrm{hr} \quad(18 \mathrm{~atm}) \\ \text { 蒸気便用量 } & 3 \mathrm{t} / \mathrm{hr} \quad(2 \cdot 5 \mathrm{~atm}) \\ \text { 酸䒺使用量 } & 3,500 \mathrm{~m}^{3} / \mathrm{hr}\end{array}$

(97〜98\% $\mathrm{O}_{2}$ として)

試験装置汇上る経験から大体この程度の能力方䋂消 単位のようで焉る。

\section{III. 炉 の 構 造}

発生炬は内径 $1,800 \mathrm{~mm}$ て試験装置の場合はウォ一 タージャケットになつていたが，本装置では約３inの パイプ於ューブボイラーの上うに列てでいる(第1

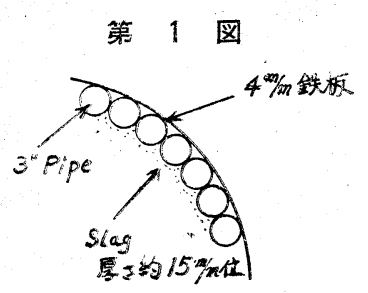

図)。発生がスはこ のパイプに沿つて上 昇して顕熱の一部炎 蒸気として回収し， さらに焒上部湤置 されたレキュペー タ一, 次のスーパモーター，衩よびボイラ一給水の予熱のためのエコ， マイザーをと和つてさらに顕熱を回収する。

吹达ノッ゙ルは原粼用のあの6本，がス化媒体用の的 の 6 本方艾互に発生炬に対し切線方向の稍下何き取 付けられている(第2図)。ノッ゙ルの取付位置はスラッ グのォーバーフローパイプの高さと大体同し高さで, 原料用ノッ゙ルの内径は $32 \mathrm{~mm}$ でがス化媒体用の方は少 し太いようである。 


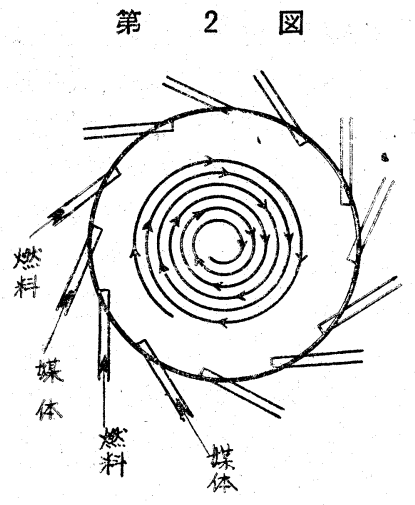

ガス化媒体としては過熱蒸気と酸素を混合して使用 する。原料とガス化媒体はそれぞれのノッ゙ルから高速 度で师内に吹さ込香れるので炉内部の液状のスラッグ は流れのエネルギによつて廻転運動を続ける。微粉の 原料宸素が灰の融点以上の高温度，すなわら 1,600 $1,800^{\circ} \mathrm{C}$ でがス化されるが，このように高速度で廻転 しているので反応物質の連続的な，杰た密接な混合が 有效心行われ，そのため沉反応子速くから炉断面積当 りの原料观理量子大となる。

师底に溜つたスラッグは新しく生成される量に相当 方量だけ連続的に中央のオーバーフローパイプから 溢流して下部のウォターシールボックスに落下して急 冷きれて粒状となり，底部のバケットコン心゙ャーで自 動的に搬出される(第3図)。

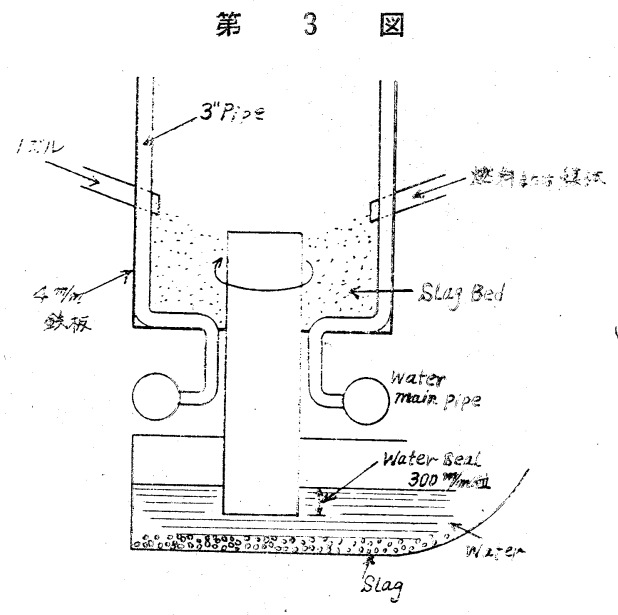

\section{N. 反藻経過}

邵内の反店としては次の経過をたどるるのと思われ To

$\mathrm{C}+\mathrm{O}_{2}=\mathrm{CO}+97 \mathrm{kcal} / \mathrm{mol}$

$\mathrm{C}+\mathrm{CO}_{\mathrm{q}}=2 \mathrm{CO}-38 \mathrm{kcal} / \mathrm{mol}$
$\mathrm{C}+\mathrm{H}_{2} \mathrm{O}=\mathrm{CO}+\mathrm{H}_{2}-28 \mathrm{kcal} / \mathrm{mol}$

$\mathrm{CO}+\mathrm{H}_{2} \mathrm{O}=\mathrm{CO}_{2}+\mathrm{H}_{2}+10 \mathrm{kcal} / \mathrm{mol}$

愹融スラッグも票たガス化反応に関係がある。すな わちその成分中の酸化鉄は一部炭素によつて次式のよ らに還元される。

$\mathrm{Fe}_{2} \mathrm{O}_{3}+\mathrm{C}=2 \mathrm{FeO}+\mathrm{CO}$

この還元されたは $\mathrm{FeO}$ 再びガス化媒体, 特に酸素 によつて酸化される。

$2 \mathrm{FeO}+\mathrm{t} / 2 \mathrm{O}_{2}=\mathrm{Fe}_{2} \mathrm{O}_{3}$

スラッグはこのよ5に酸美の誘導体として働きま た触媒のよ5にガス化反応の促進を助ける。

なた反応速度はスラッグの成分之粘度に大きな関係 がある。すなわちサラサラしたスラッグの中てはがス 状の反応参加物は小さい気泡となり，その結棵反底表 面積が大となり反応速度は速くなる。

原料中の無機牧よび有機の硫璜はスラッグの高温 之, 师内を支配している還元気の中で絶えず硫化水素 に変化して有機硫黄化合物や䊀脂生成物は生成されな w。

\section{V.Wesseling エ場の裝置および作業の概要}

この工場では原料は附近で採掘されるライン褐炭を 使用している。原料の条件としては次のことがあげら 剠ている。

\section{(1) 粒 度}

峞質は如何なるものでる差支えないが粒度は 0〜 $2 \mathrm{~mm}$ とすることが経験上最もよいよ 5 である。 Ottoでは 2〜 $5 \mathrm{~mm}$ でる支障ないように設哔できる といりている。この工場では0〜3mm使用してい るが，3〜 $5 \mathrm{~mm}$ が $20 \%$ 程なら混入乙ても問題にな らないようである。

(2) 灰の熔流点 (Flowing point)

灰の愹流点は $1,450^{\circ} \mathrm{C}$ 以下が好本しいが，先しろ 重要なことはスラッグがいわゆる “long slag”で あるか, “short slag”であるかという点である。

“short slag”で岗机ばたとえ愹流点が $1,450^{\circ} \mathrm{C}$ 以 上であつても差支えない場合がある。またもし愹流 点が高くてスラッグが液状になら双場合は融剤を入 れることるでさる。

装置の概要は第 4 図に示すと新りで，原料は原料バ ンカーからビューラーコン心゙ャーで建物最上部にある 網目 $3 \mathrm{~mm}$ の振動篩にかけて, 篩上は次の粉砕機で粉 砕して再穊する。 $3 \mathrm{~mm}$ 以下の原料は温合槽でよく混 合した後計量装置をと和つて原料ポンプで炉内に吹き 込む。この原料ポンプの流動体としては炭酸がスを使 用している。（蒸気，水蒸気でるよいが，この工場で 


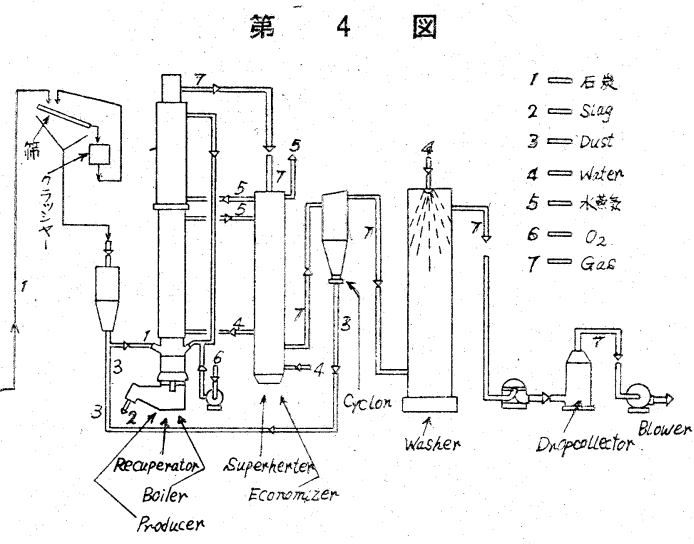

は余剩の炭酸ガスがあるので使用している。)発生がス は前述のようにレキュペレーター,スーパーューター, エコノ、マイザーを通過してサイクロンに大り，ガスと 共に飛散してくるカーボン，スラッグを分離する。こ の分離されたカーボン，スラッグは再び発生炉に吹き 込む。この量は原料の約 $10 \%$ 程度で原料吹込用ノッ゙ル の中 1 本をこのために使用している。サイクロンを出

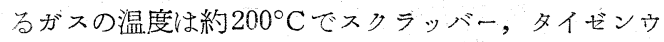
オッシャー，ドロップキャッチャーを経てダストを除 去し, ガス温度も約 $25^{\circ} \mathrm{C}$ 本で领却してブロワーで合 成工場へ送つている。ガス精製設備の大さは次のと稆 りである。
(1) スクラッバー 1 基
内径 $3.6 \mathrm{~m}$ 高 $16.8 \mathrm{~m}$
ガス通過量 $16,000 \mathrm{~m}^{3} / \mathrm{hr}$
所要馬力数 $150 \mathrm{HP}$
（2）タイゼンウォッシャー 2 基
（3）ガスブロワー２基（1基予備）
所要馬力数 $52 \mathrm{H}$
（4）酸素ブロワー 2 基（1 基予備）
所要馬力数 $90 \mathrm{HP}$
（5）給水ポンプ 2 基

$$
\text { 能力 } 113 \mathrm{~m}^{3} / \mathrm{hr}
$$

（6）鉄鋼構築物（計器室，ブロワー窒を含めて）

$$
\begin{array}{lll}
\text { 総 重·量 } & 140 \mathrm{t} \\
\text { 床 面 積 } & 8 \mathrm{~m} \times 36 \mathrm{~m} \\
\text { 高 さ } & 15 \mathrm{~m}
\end{array}
$$

（7）全装置の鉄鋼総重量（基礎材料を除く）

$$
1,200 \mathrm{t}
$$

蒸気はこの装置で $18 \mathrm{~atm}, 350^{\circ} \mathrm{C}$ の高圧加熱壑気が 発生するが，使用蒸気は $2.5 \mathrm{~atm}, 140^{\circ} \mathrm{C} て ゙$ 充分である ので発生蒸気は合成工場に送り，合成工場の余甜蒸気 在使用している。
酸素はリンデ酸素発生装置で製造しているので純度 97〜98\%のものを使用しているが, 蒸気と混合して使 用するので必ずしも純度の高いるのを必要としない。

この装置の全般的な管理は中央管理室で中央制御し ているので，作業員は 1 交代当り，石炭関係 1 人，発 生炉関係 1 人, 機械䞟り関係 1 人, 計 3 人で発生炉二 基柰で作業できるといつているから予備員委で含めて も10人で充分である。

この発生师の発生作業開始の場合はまずスラッグオ 一バーパイプの上に板を敖き，その上に焚木を積ん で点火し，石炭と空気を徐々に吹き込む。約20２4時 間後, 充分にスラッグぶッドができて炉内の温度が上 昇した時に空気を酸素と過熱蒸気に切替元て平常作菜 となる。休止後の発生の場合は炉内にスラッグぶッド が形成されているので同様な方法で点火して平常作業 に移るまで約 8 時間である。休止の場合は原料と酸

\begin{tabular}{|c|c|c|}
\hline 水 & 分 & $8 \%$ \\
\hline 揮 発 & 分 & $44 \sim 45 \%$ \\
\hline 扊 & 分 & $5 \sim 6 \%$ \\
\hline 硫＼cjkstart黄 & 分 & $0.4 \%$ \\
\hline 融 & & $1,350 \sim 1,400^{\circ} \mathrm{C}$ \\
\hline & & $5,000 \mathrm{kcal} / \mathrm{kg}$ \\
\hline
\end{tabular}
素, 過熱蒸気の吹込夕を同時に停止して放置すると約 5 時間で冷却する。

\section{VI.Wesseling エ場における作業成績}

（1）原料褐炭の分析

(2) 灰の組成

ガス化前の褐炭より分析した扊の組成の一例

$\begin{array}{lr}\mathrm{SiO}_{2} & 6 \% \\ \mathrm{Fe}_{2} \mathrm{O}_{3} & 22 \% \\ \mathrm{Mg}_{3} \mathrm{O}_{4} & - \\ \mathrm{Al}_{2} \mathrm{O}_{3} & 6 \% \\ \mathrm{CaO} & 45 \% \\ \mathrm{MgO} & 4 \% \\ \mathrm{SO}_{3} & 17 \%\end{array}$

(3) 発生ガスの分析

$\begin{array}{lc}\mathrm{CO}_{2} & 15 \sim 16 \% \\ \mathrm{CnHm} & 0.2 \% \\ \mathrm{CO} & 40 \sim 41 \% \\ \mathrm{O}_{2} & 0.2 \% \\ \mathrm{CH}_{4} & 0.5 \% \\ \mathrm{H}_{2} & 36 \sim 37 \% \\ \mathrm{H} . \mathrm{V} & 2,600 \sim 2,700 \mathrm{kca}: / \mathrm{m}^{3}\end{array}$

(4) 作業原単位（1時間当り）

褐炭使用量 9,500kg. 


$$
\begin{aligned}
& \text { 酸素使用量 } \quad 3,200 \mathrm{Nm}^{3} \\
& \text { 蒸気使用量 } \quad 2,200 \mathrm{~kg} \\
& \left(2.5 \mathrm{~atm}, 140^{\circ} \mathrm{C}\right) \\
& \text { 炭酸ガス使用量 } 600 \mathrm{Nm}^{3} \\
& \text { スラッグ生成量 } \quad 400 \mathrm{~kg} \\
& \text { 蒸気発生量 } 9,000 \mathrm{~kg} \\
& \text { (18atm } 350^{\circ} \mathrm{C} \text { ) } \\
& \text { スクラッバー用 } 130 \mathrm{~m}^{3} \\
& \text { タイゼンウォッシャー用 } 16 \mathrm{~m}^{3}
\end{aligned}
$$

(5) その他の数值

(i) ガス温度

$$
\begin{array}{lr}
\text { 炉の底部 } & 1,600^{\circ} \mathrm{C} \\
\text { レキュペレーター大口 } & 900^{\circ} \mathrm{C} \\
\text { スーパーヒーター大ロ } & 730^{\circ} \mathrm{C} \\
\text { サイクロン大ロ } & 220^{\circ} \mathrm{C} \\
\text { スクラッバー出ロ } & 25^{\circ} \mathrm{C} \\
\text { タイゼンウォッシャー出口 } & 23^{\circ} \mathrm{C}
\end{array}
$$

(ii) ガス中のダスト

$$
\begin{array}{lr}
\text { スクラッバー出口 } 20 \mathrm{mg} / \mathrm{m}^{3} \\
\text { タイゼンウォッシャー出口 } 5 \mathrm{mg} / \mathrm{m}^{3}
\end{array}
$$

(iii) 使用圧力

$$
\begin{array}{lrr}
\text { 炭酸 ガス } & \text { 2atm } \\
\text { 酸 } & \text { 素 } & 2,000 \mathrm{~mm} \text { (水柱) } \\
\text { 蒸 } & \text { 気 } & 2.5 \mathrm{~atm} \\
\text { 給 } & \text { 水 } & 18 \mathrm{~atm}
\end{array}
$$

\section{VII・スラッグベッドガス発生炉の特長}

この発生师の特長としては次の点があげられてい 万。

（1）原料は炭種な選ばず高灰分でも美支えない。 束た粒度も0〜 $3 \mathrm{~mm}$ 程度のものが使用できる。

(2) 流鍰炉の上うな融㲏が不要である。

（3）連続作業ができる。このためバルブの開閉も なく比較的楧造が籃単になり資本費も少くてす 它。

（4）微粒の炭素が大きな表面積と灰の融点以上の 高温度でガス化されるので，反応速度が速く，炉
の断面積当りの処理能力が大である。

（5）空気，蒸気，酸素，炭酸が ス等の使用制合の 変化により発生炉がス，水性がス，合成用がスな ぞの用途に適合したガスの製造が容易である。李 た重油の使用（原料吹込ノズルの一部または全部 をステームジェット式ノッ゙ルと取替兄て重油を吹 き込さ。)によつて堌熱水性がス，或は油がスの製 造もできる。

（6）重炭化水素，タールは活とんど分解されて生 成されない。

（7）石炭中の硫黄分はほとんど全部硫化水素とな り,有機硫黄化合物や樹脂生成物は生成されない。 (このことは特に合成用がスとしては重要なこと である。)

（8）ガス化效率は 80\%を超宇る。

(9) 熱效率は93\%以上となり非常に高い。

（10） スラッグは完全に燃焼性物質を含李ないの で，スラッグ粒にすることもスラッグウールにす ることもできる。

\section{IIII. 結}

このスラッグぶッドガス発生炉は現在合成用ガス製 造の目的で作業されているが，前述のようにガスの成 分すなわら水素と一酸化炭素の量を比較的容易に変化 することができるので今後合成用がス源として相当利 用価值のあるるのと思われる。都市がス用としてはこ の発生炉単独では適当ではないが，重油に上る増熱を して使用することも今後研究する必要がある。库た現 在コークス発生炉を使用している代りにこの発生炉を 使用して高熱量油がスの稀翻用がスを製造すること は，酸素を必要とする欠点はあるが，コークス発生炉 に比較して

(1) 低品位炭が使用できること。

（2）がス得熱和よびがス熱量が高いこと。

（3）ガス中の水素含有量が多いこと。

（4）成分的に操業上の弾力性に富九でいることな どの利点を有しているのでがス事業者としても今 後興味むる研究課題だと思われる。 


\title{
Otto Slag Bed Gasifier
}

\author{
by Ryoichi Takashima
}

(Tokyo Gas Co.)

SYNOPSIS:-The consumption of coal in every country increases year by year and especially coking coal is gradually subjected to many restrictions.

Except U. S. and Italy which abound in petroleum resources, many countries are faced to the circumstances under which they must rapidly devolop the gasification of noncaking coal or low-grade coal.

The studies of complete gasification of non-caking coal progress in Germany and following the Lurgi high pressure gasfier and the Coppers-Totzek gasification furnace which have already been put into commercial operation, Otto slag bed gasifier was established in 1956 at the Wesseling synthetic works in Cologne near Düsseldorf and has heen successfully operated.

The author describes in this paper the outline of this gasifier and its operation results.

\section{気一液分配クロマトグラフィーによる定量に用いる面積の解析}

L. C. Browning \& J. O. Watts, Anal. Chem. 29, (1) 24 7 (1957)

気一液分配クロマトグラフィーによる定量厄就いて,成分の熱伝導度が大体同じならば記録された 曲線で囲变れた面積恃直接成分の wt \% に比例している。成分の熱伝導度で面積をわるととによつ

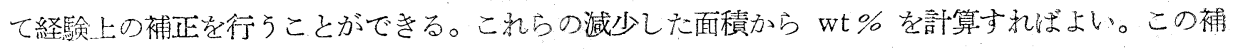
正を水一エチルアルコールージェチルェーテル,水一ェチルアルコール, 四盐化炭素一アセトン, エ チルアルコールークロロホルム, 四塩化炭素-ークロロホルム就よで別の著者が報告した炭化水素類の 溶液に応用したが大体に执いてよい結果が得られた。

直接的の補正はるつとも正確な結果劣与光る。 